\title{
Sintesis dan Aplikasi Karboksimetil Kitosan sebagai Inhibitor Korosi pada Baja Karbon dalam Air
}

\author{
Maria Erna $^{\left.{ }^{*}\right)}$, Emriadi $^{2)}$, Admin Alif ${ }^{2)}$, Syukri Arief ${ }^{2)}$ and Mohd. Jain Noordin ${ }^{3)}$ \\ 1)Program Studi Pendidikan Kimia, Fakultas Keguruan dan Ilmu Pendidikan, Universitas Riau, \\ Kampus Binawidya km 12,5, Panam, Pekanbaru, 28293 \\ 2)Jurusan Kimia, Fakultas Matematika dan IImu Pengetahuan Alam, Universitas Andalas, Padang \\ 3)PPS Kimia, Universiti Sains Malaysia, Penang \\ Diterima 10-04-2009 Disetujui 02-07-2009
}

\begin{abstract}
Carboxymethyl chitosan (CMC) was synthesized with different methods by reacting chitosan with monochloroacetic acid in the presence of sodium hydroxide under variation conditions. The above samples were characterized by Fourier transform infrared spectroscopy (FTIR) and soluble in water in range of $\mathrm{pH}$. The CMc were soluble in water a wide range of $\mathrm{pH}$ and applied as corrosion inhibitor for steel in water. The inhibiting influence of CMC was studied by potentiodynamic polarization method. It was found thad corrosion rate was dependent on water $\mathrm{pH}$ and $\mathrm{CMC}$ concentration. The results show that optimum the inhibition efficiency at $\mathrm{pH} 5$ and $1 \mathrm{ppm}$ concentration $\mathrm{CMC}$, i.e., $77 \%$. The adsorption of used compound on the steel surface obeys modified Langmuir isotherm. Polarization measurement show that the CMC acts essentially as a anodic-type inhibitor.
\end{abstract}

Keywords: adsorption, anodic inhibitor, carboxymethyl chitosan, inhibition corrosion

\section{PENDAHULUAN}

Karboksimetil kitosan (KMK) merupakan turunan kitosan yang berasal dari kitin yang diisolasi dari invertebrata laut (misalnya udang dan kepiting), darat, serangga, jamur serta ragi. Pada invertebrata, kitin berfungsi sebagai matriks penyusun eksoskeleton, sedangkan pada jamur berfungsi sebagai pembentuk dinding sel. Kitosan bersifat padatan, larut dalam asam asetat dan mudah didegradasi serta dapat dimanfaatkan sebagai bahan dasar dalam bidang industri, kesehatan maupun kosmetik. Tetapi aplikasi kitosan terbatas sebab tidak larut dalam air (de Abreu \& Campana Filho, 2008)

KMK mempunyai sifat yang penting yaitu larut dalam air, kapasitas pembentukan gel tinggi, toksisitas rendah dan biokompatibel baik, sehingga aplikasinya akan lebih luas (Xue et al., 2009). Contoh aplikasi KMK sebagai antimikroba, antioksida, resin, adsorben, inhibitor korosi pada baja lunak dan digunakan sebagai bahan baku membran, masing-masing dilaporkan oleh Sun L et al., (2006), Sun S et al., (2008), Sun S et al., (2006), Wang et al., (2008), Cheng et al., (2007) dan Jing et al., (2008). KMK banyak penggunaannya karena

\footnotetext{
*Telp: +628127613472

Email: buuerna@yahoo.com
}

bersifat amphiprotik, hal ini sebabkan KMK mengandung gugus- $\mathrm{COOH}$ dan- $\mathrm{NH}_{2}$ dalam molekulnya yang kaya akan pasangan-pasangan elektron bebas.

Metode yang digunakan untuk mensintesis KMK pada penelitian ini adalah metode yang dilaporkan oleh Zhou et al., (2006), Pang et al., (2007), Wang et al., (2008), dan Liang et al., (2008). Gugus fungsi KMK dianalisa menggunakan Spektroskopi FT-IR dan diuji kelarutannya dalam air pada berbagai $\mathrm{pH}$. Sedangkan bahan bakunya yang digunakan untuk mensintesis KMK adalah kitosan yang diproduksi oleh Laboratorium Analitik Jurusan Kimia, IPB.

Pada penelitian ini KMK yang larut dalam air pada berbagai pH diaplikasikan sebagai inhibitor korosi pada baja dalam air. Korosi pada baja merupakan masalah terbesar di Indonesia karena termasuk negara tropis yang memiliki curah hujan cukup tinggi dan kelembaban yang tinggi. Sudah banyak dilakukan upaya pencarian inhibitor korosi menggunakan senyawa organik, misalnya juice buah dari citrus paradise yang kaya dengan vitamin $C$, asam folat dan vitamin lainnya, pektin, flavonoid terbukti mengurangi laju korosi dalam lingkungan asam (Abiola et al., 2004). Kemudian getah guar telah diuji sebagai inhibitor korosi untuk baja karbon dalam larutan $1 \mathrm{M} \mathrm{H}_{2} \mathrm{SO}_{4}$ menunjukkan efisiensi 
inhibisi meningkat dengan meningkatnya konsentrasi getah guar (Abdallah M, 2004). Dan ekstrak teh hijau diselidiki mampu menginhibisi korosi (Vincent et al., 2005). Adapun kelemahan dari inhibitor di atas adalah sumbernya terbatas di alam. Adapun KMK bahan bakunya yaitu kitosan merupakan polimer alami yang sumbernya dialam terbesar setelah selulosa.

Efisiensi inhibisi korosi KMK dipelajari secara eksperimen elektrokimia yaitu menggunakan potensiometer. Parameter yang akan dipelajari adalah variasi $\mathrm{pH}$ dan konsentrasi KMK terhadap persentase efisiensi inhibisi korosi. Jenis adsorpsi inhibisi KMK pada permukaan baja dipelajari menggunakan persamaan adsorpsi isotherm Langmuir. Dari persamaan ini didapatkan data konstanta adsorpsi $\left(\mathrm{k}_{\mathrm{ads}}\right)$ dan energi bebas adsopsi $\left(\Delta \mathrm{G}^{\circ}\right)$. Jenis inhibitor KMK ditentukan menggunakan kecenderungan pergeseran nilai potensial korosi $\left(E_{\text {corr }}\right)$ pada kuva polarisasi yang didapatkan.

\section{BAHAN DAN METODE}

Bahan yang digunakan adalah kitosan (laboratorium kimia analitik IPB), $\mathrm{NaOH}, \mathrm{HCl}$, aseton, isopropanol, monokloroasetat, etanol, lempengan baja karbon (C 1,97\% dan Fe 98,03\%), kertas pasir karbit silikon (100, 200 dan 400-grit), $\mathrm{HCl}, \mathrm{NaOH}$ dan aquades.

Sedangkan alat-alat yang digunakan adalah oven, timbangan analitik, Shaker, Waterbath, Stirrer, peralatan refluk, Potensiostat, Fourier Transform Infrared Spectroscopy (FT-IR), dan peralatan gelas yang umum dipakai.

Ada empat metode yang digunakan untuk mensintesis KMK dengan bahan kimia yang sama tetapi jumlah dan tahap penggunaannya yang berbeda. Pertama Metode Zhou et al., (2006) yaitu kitosan $5 \mathrm{~g}$ ditambahkan isopropanol $75 \mathrm{~mL}$ dan $\mathrm{NaOH}(40 \%) 125$ $\mathrm{mL}$ serta diaduk. Campuran direfluk pada $60^{\circ} \mathrm{C}$ selama 1 jam dan ditambahkan isopropanol $100 \mathrm{~mL}$ yang mengandung asam monokloroasetat $30 \mathrm{~g}$ tetes demi tetes selama 1 jam hingga reaksi bercampur. Setelah 4 jam ditambahkan etanol (70\%) $250 \mathrm{~mL}$ untuk menghentikan reaksi. Padatan disaring dan dicuci dengan etanol $90 \%$ dan dikeringkan pada $50^{\circ} \mathrm{C}$.

Metode kedua menurut Wang et al., (2007) yaitu kitosan 5 g ditambahkan $\mathrm{NaOH}(20 \%) 50 \mathrm{~mL}$ selama 12 jam pada temperatur ruang, lalu disaring, dan ditambahkan isopropanol $50 \mathrm{~mL}$ dan di stirrer selama 30 menit pada temperatur ruang. Lalu ditambahkan isopropanol $100 \mathrm{~mL}$ yang mengandung asam monokloroasetat 3,58 $\mathrm{g}$ dan distirrer selama 30 menit dan campuran dipanaskan selama $60^{\circ} \mathrm{C}$ selama 1 jam. Selanjutnya disaring dan dicuci dengan etanol $70 \%$ sebanyak 3 kali dan etanol 90\% sekali. Padatan dikeringkan pada $80^{\circ} \mathrm{C}$.

Metode ketiga adalah menurt Pang et al., (2007) yaitu kitosan $1 \mathrm{~g}$ ditambahkan $\mathrm{NaOH}$ 1,35 g, dan pelarut (aquadest $2 \mathrm{~mL}$ dan Isopropanol $8 \mathrm{~mL}$ ), lalu dimasukkan ke dalam waterbath $60^{\circ} \mathrm{C}$. Kemudian ditambahkan asam monokloroasetat $1,5 \mathrm{~g}$ yang telah dilarutkan ke dalam isopropanol $2 \mathrm{~mL}$ dan direaksikan selama 4 jam. Reaksi dihentikan dengan menambahkan etanol $70 \%$ sebanyak $20 \mathrm{~mL}$. Padatan disaring dan dicuci dengan etanol $90 \%$ serta dikeringkan pada temperatur ruang.

Metode keempat adalah menurut Liang et al., (2008) yaitu Kitosan $1 \mathrm{~g}$ tambahkan $\mathrm{NaOH}$ (40\%) 15 $\mathrm{mL}$, lalu dipanaskan pada $20^{\circ} \mathrm{C}$ semalaman. Kemudian tambahkan isopropanol $100 \mathrm{~mL}$ yang mengandung asam monokloroasetat 0,5 g dan diaduk pada temperatur ruang selama 12 jam. Kemudian tambahkan etanol $90 \%$, disaring dan dicuci dengan etanol.

Karakterisasi gugus fungsi Karboksimetil Kitosan digunakan Spektrometer FT-IR ( A Perkin Elmer System 2000) dengan cara KMK digerus dan dibuat dalam bentuk pellet $\mathrm{KBr}$. Sedangkan kelarutan KMK ditentukan dengan cara menimbang KMK 0,01 mg dan ditambahkan aquadest $10 \mathrm{~mL}$ dengan variasi $\mathrm{pH}$ (113), $\mathrm{pH}$ diatur menggunakan $\mathrm{HCl}$ dan $\mathrm{NaOH}$. Lalu dilihat kelarutannya.

Persiapan peralatan elektrokimia sebagai berikut: Tiga cell elektroda ( steel working electrode, WE dengan luas permukaan $1,0 \mathrm{~cm}^{2}$, platinum counter electrode (CE) dan saturated colamel reference electrode (SCE). Potensiostat PGP 201 yang terhubung ketiga cell elektroda. Software Voltamaster 4. Dengan kemudian disiapkan spesimen baja $2 \mathrm{~cm} \mathrm{x}$ $4 \mathrm{~cm}$ digosok permukaannya dengan kertas pasir karbit silikon 100, 200, 400-grit dan dibilas dengan aseton. Kemudian dikeringkan dalam oven pada suhu $40^{\circ} \mathrm{C}$ selama 15 menit.

Disiapkan air dengan variasi $\mathrm{pH}(4,5,6,7,9$, dan 11) dan variasi konsentrasi $\operatorname{KMK}(0,8,1,3$, 5, dan $7 p p m)$. Spesimen baja ditempatkan pada peralatan elektrokimia yang dihubungkan dengan Potenstiostat. 
Dan siap untuk dirun dan ditentukan parameter elektrokimianya.

Jenis adsorpsi pada permukaan baja pada penelitian ini dipelajari menggunakan persamaan isotherm Langmuir yang menganggap terbentuk adsorpsi monolayer dengan persamaan: $\frac{C}{\theta}=\frac{n}{K_{a d s}}+n C$

dimana $C$ adalah konsentrasi , $n$ dan $K_{a d s}$ adalah koefisien adsorpsi dan $\theta$ adalah luas permukaan baja yang tertutup yang dihitung menggunakan persamaan:

$\theta=\frac{\mathrm{R}_{1}-\mathrm{R}_{2}}{\mathrm{R}_{1}}$

dimana $R_{1}$ dan $R_{2}$ berturut-turut adalah laju korosi tanpa dan dengan inhibitor. Jika diplotting $C / \theta$ terhadap C membentuk garis lurus, maka peristiwa tersebut mematuhi persamaan isotherm Langmuir. Nilai energi bebas adsorpsi $\left(\Delta G^{\circ}{ }_{\text {ads }}\right)$ dapat dihitung dari persamaan: Dimana, $T$ adalah temperatur absolut dan $R$ adalah konstanta gas.

$K_{a \mathrm{ads}}=\frac{1}{55,5} \exp \left(-\frac{\Delta G^{o}{ }^{o} \mathrm{ds}}{R T}\right)$

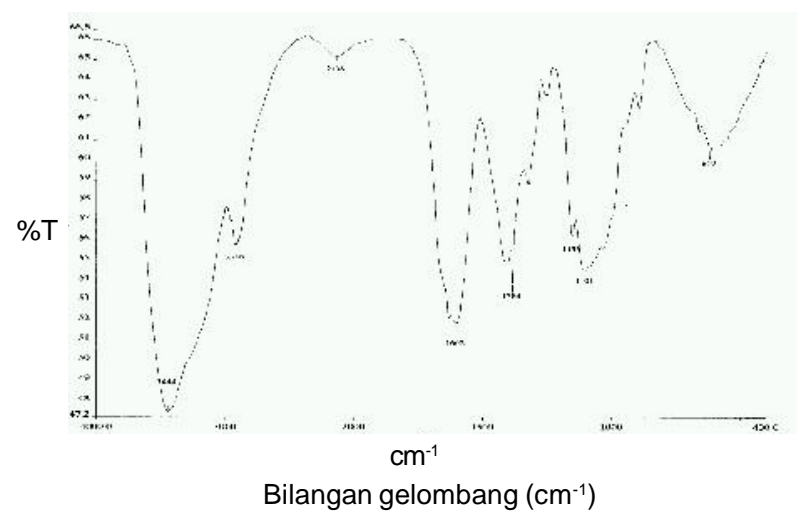

Gambar 2. Spektrum FT-IR Karboksimetil Kitosan metode Wang, (2007)

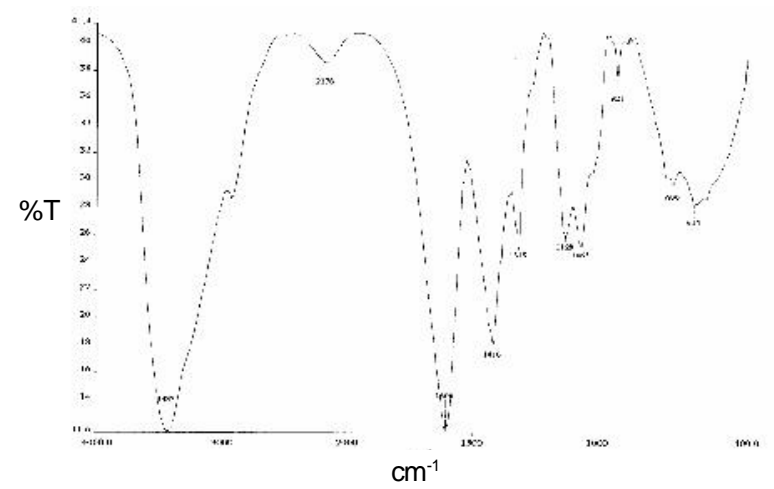

Bilangan gelombang $\left(\mathrm{cm}^{-1}\right)$

Gambar 3. Spektrum FT-IR Karboksimetil Kitosan metode Pang, (2007)
Jenis inhibitor ditentukan berdasarkan data eksperimen elektrokimia yang dibuat dalam bentuk kurva potensiodinamik yang diperoleh dari plot Tafel yaitu ektrapolasi bagian linear dari kurva potensial korosi $\left(E_{\text {corr }}\right)$. Jika pergeseran $E_{\text {corr }}$ kearah potensial posiitf disebut jenis inhibitor anodik dan sebaliknya jika bergeser ke potensial negatif disebut inhibitor katodik.

\section{HASIL DAN PEMBAHASAN}

Hasil spektrum FT-IR dari keempat metode yang digunakan untuk mensintesis KMK dapat dilihat dari Gambar 1-4, menunjukkan bahwa spektrum FT-IRKMK yang disintesis dengan metode Pang, 2007 yang sama dengan referensi. Terlihat bahwa vibrasi stretching gugus $\mathrm{O}-\mathrm{H}$ dan $\mathrm{N}-\mathrm{H}$ terjadi pada $3437 \mathrm{~cm}^{-1}$ dan puncak khas KMK terjadi pada 1606 dan $1416 \mathrm{~cm}^{-1}$ yaitu gugusCOO- yang menunjukkan karboksimetilasi terjadinya pada gugus amino kitosan. Puncak $1065 \mathrm{~cm}^{-1}$ menjadi lebih tajam dan puncak alkohol primer pada $1030 \mathrm{~cm}^{-1}$ tidak signifikan, hal ini menunjukkan bahwa karboksimetilasi terjadi pada gugus hidroksil primer pada kitosan. Berdasarkan analisa spektrum FT-IR ini menyatakan KMK yang terbentuk merupakan N,O-KMK

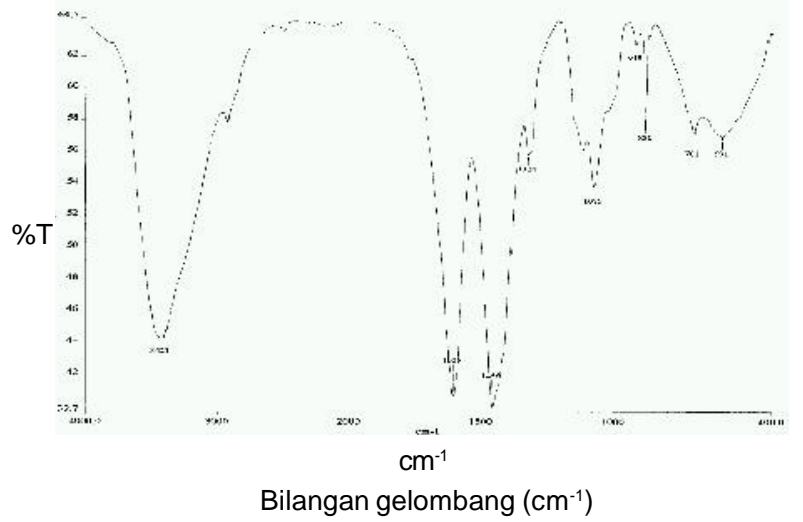

Gambar 1. Spektrum FT-IR Karboksimetil Kitosan metode Zhou, (2006)

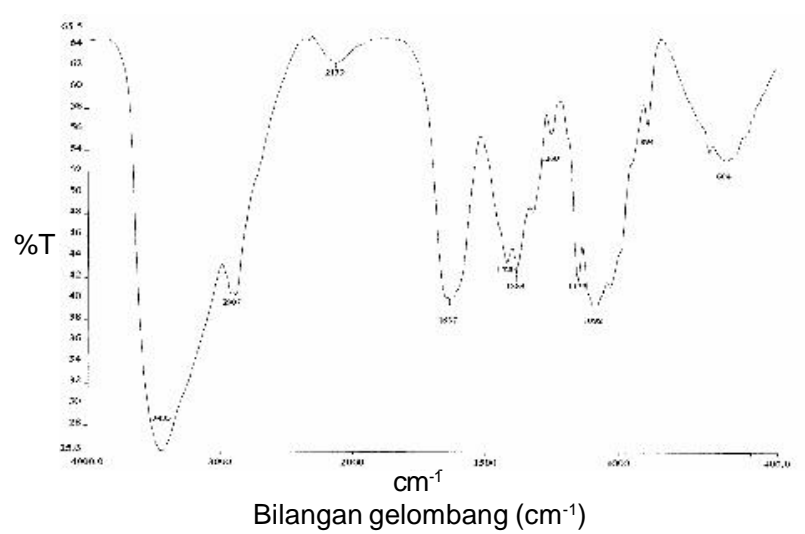

Gambar 4. Spektrum FT-IR Karboksimetil Kitosan metode Liang, (2008) 
yaitu gugus karboksimetil terjadi pada posisi $\mathrm{N}$ dan $\mathrm{O}$. (Liu et al., 2001).

Tabel 1. menunjukkan bahwa dari keempat metode yang digunakan untuk mensintesis KMK, hanya metode Pang yang larut dalam air pada semua $\mathrm{pH}$, hal ini disebabkan KMK yang disintesis mengandung gugus-COO- yang merupakan garam asam karboksilat (Xue et al., 2009) yang berperan dalam kelarutan. Hal ini didukung dengan bentuk spektrum FT-IR yang memperlihatkan puncak $1606 \mathrm{~cm}^{-1}$ dan $1416 \mathrm{~cm}^{-1}$ yang lebih tajam dibandingkan dengan metode lain. Ini menunjukkan bahwa derajat subtitusi pada KMK yang disintesis lebih tinggi.

Berdasarkan data eksperimen elektrokimia didapatkan parameter potensial korosi $\left(E_{\text {corr }}\right)$, konstanta Tafel anoda $\left(\mathrm{b}_{\mathrm{a}}\right)$ dan katoda $\left(\mathrm{b}_{\mathrm{c}}\right)$, rapatan arus korosi $\left(I_{\text {corr }}\right)$ dan laju korosi $(R)$. Nilai efisiensi inhibisi (\% El) dihitung menggunakan persamaan berikut (Rahim A.A et al., 2007):

$\mathrm{EI}(\%)=\frac{\mathrm{i}_{\text {corr }}-\mathrm{i}_{\text {corr }}^{\prime}}{\mathrm{i}_{\text {corr }}} \times 100$

$\mathrm{i}_{\text {corr }}=$ Rapatan arus tanpa inhibito

$i_{\text {corr }}^{\text {corr }}=$ Rapatan arus dengan menggunakan inhibitor

Gambar 5. menunjukkan bahwa laju korosi baja dipengaruhi oleh $\mathrm{pH}$ air. Pada $\mathrm{pH} 5$ laju korosi paling minimum yaitu 1,192 mpy (mil/tahun), hal ini disebabkan KMK bersifat amphiprotik (Sun et al., 2006), dalam suasana asam lemah yaitu gugus $-\mathrm{NH}_{3}{ }^{+}$ akan teradsorpsi dalam orbital-d Fe yang setengah

Table 1. Kelarutan KMK 1mg/L dalam air pada temperatur ruang Metode

\begin{tabular}{llllllllllllll} 
& 1 & 2 & 3 & 4 & 5 & 6 & 7 & 8 & 9 & 10 & 11 & 12 & 13 \\
\hline Zhou & $\mathrm{L}$ & $\mathrm{L}$ & $\mathrm{L}$ & $\mathrm{L}$ & $\mathrm{TL}$ & $\mathrm{TL}$ & $\mathrm{TL}$ & $\mathrm{TL}$ & $\mathrm{L}$ & $\mathrm{L}$ & $\mathrm{L}$ & $\mathrm{L}$ & $\mathrm{L}$ \\
Wang & $\mathrm{L}$ & $\mathrm{L}$ & $\mathrm{L}$ & $\mathrm{L}$ & $\mathrm{TL}$ & $\mathrm{TL}$ & $\mathrm{TL}$ & $\mathrm{TL}$ & $\mathrm{TL}$ & $\mathrm{L}$ & $\mathrm{L}$ & $\mathrm{L}$ & $\mathrm{L}$ \\
Liang & $\mathrm{L}$ & $\mathrm{L}$ & $\mathrm{L}$ & $\mathrm{TL}$ & $\mathrm{TL}$ & $\mathrm{TL}$ & $\mathrm{TL}$ & $\mathrm{TL}$ & $\mathrm{TL}$ & $\mathrm{L}$ & $\mathrm{L}$ & $\mathrm{L}$ & $\mathrm{L}$ \\
Pang & $\mathrm{L}$ & $\mathrm{L}$ & $\mathrm{L}$ & $\mathrm{L}$ & $\mathrm{L}$ & $\mathrm{L}$ & $\mathrm{L}$ & $\mathrm{L}$ & $\mathrm{L}$ & $\mathrm{L}$ & $\mathrm{L}$ & $\mathrm{L}$ & $\sqrt{ }$ \\
\hline
\end{tabular}

Keterangan: $\mathrm{L}=$ Larut dan $\mathrm{TL}=$ Tak larut

Tabel 2. Parameter elektrokimia Baja dalam $\mathrm{H}_{2} \mathrm{O}$ variasi konsentrasi $\mathrm{KMK}$ pada $\mathrm{pH} 5$

\begin{tabular}{|c|c|c|c|c|c|}
\hline $\begin{array}{c}\text { Konsentrasi } \\
\text { (ppm) }\end{array}$ & $\begin{array}{l}E_{\text {corr }} \\
(\mathrm{mV})\end{array}$ & $\begin{array}{c}\mathrm{I}_{\text {corr }} \\
(\mu \mathrm{A} / \mathrm{cm} 2)\end{array}$ & $\mathrm{b}_{\mathrm{c}}(\mathrm{mV} / \mathrm{dec})$ & $\begin{array}{c}\mathrm{B}_{\mathrm{a}} \\
(\mathrm{mV} / \mathrm{dec})\end{array}$ & $\begin{array}{c}\mathrm{R} \\
\text { (mpy) }\end{array}$ \\
\hline 0 & $-439,6$ & 0,439 & 168,9 & 167,2 & 5,144 \\
\hline 0,8 & -438.4 & 0,319 & 142.3 & 133.8 & 3.717 \\
\hline 1 & $-381,8$ & 0,101 & 83,1 & 53,9 & 1.192 \\
\hline 3 & -405.4 & 0,197 & -155.3 & 158.0 & 2.312 \\
\hline 5 & -356.5 & 0,206 & 103.8 & 103.3 & 2,424 \\
\hline 7 & -213.5 & 0,238 & 157.0 & 157.1 & 2,999 \\
\hline
\end{tabular}

penuh. Pada pH dibawah 5 laju korosi meningkat karena suasana asam kuat yang akan melarutkan Fe karena KMK kekurangan elektron. Sedangkan $\mathrm{pH}$ disuasana basa lemah juga meningkatkan laju korosi karena gugus fungsi -COO- akan mengikat Fe yang bermuatan +. Pada suasana basa kuat elektron-elektron bebas pada -COO- akan teradsopsi dalam orbital-d Fe yang setengah penuh.

Sedangkan Gambar 6. menunjukkan bahwa efisiensi inhibisi korosi paling optimum terjadi pada konsentrasi KMK 1 ppm yaitu 77\%. Hal ini didukung dengan data nilai konstanta Tafel anoda $\left(\mathrm{b}_{\mathrm{a}}\right)$ dan katoda $\left(b_{c}\right)$, rapatan arus korosi $\left(I_{\text {corr }}\right)$ dan laju korosi $(R)$ paling rendah terjadi pada konsentrasi KMK 1 ppm dapat dilihat pada Tabel 2. Kapasitas daya adsorpsi inhibitor pada permukaan baja dipengaruhi oleh struktur kimia, muatan logam dan distribusi muatan dalam molekul dan juga jenis media elektrolitnya.

Berdasarkan Gambar 7. didapatkan nilai $K_{\text {ads }}=$ $8,9105 \mathrm{M}^{-1}$ dan $\Delta G^{0}{ }_{\text {ads }}=-43,9 \mathrm{Jmol}-1$. Nilai negatif $\Delta G^{0}{ }_{a d s}$ menunjukkan proses adsorpsi terjadi secara spontan dan bersifat khemisorpsi (adsorpsi kimia), karena nilainya mendekati $-40 \mathrm{kJmol}-1$ (Bouklah et al., 2006). Hal ini disebabkan terjadi pertukaran atau transfer elektron dari molekul KMK yang kaya akan pasangan elektron bebas dari gugus fungsi $-\mathrm{OH},-\mathrm{COOH}$ dan $-\mathrm{NH}_{2}$ ke permukaan baja yang membentuk ikatan kovalen koordinasi.

Berdasarkan kurva potensiodinamik pada Gambar 12 , menunjukkan bahwa semua nilai $\mathrm{E}_{\text {corr }}$ untuk variasi konsentrasi KMK bergeser ke kurva anodik dan rapatan 


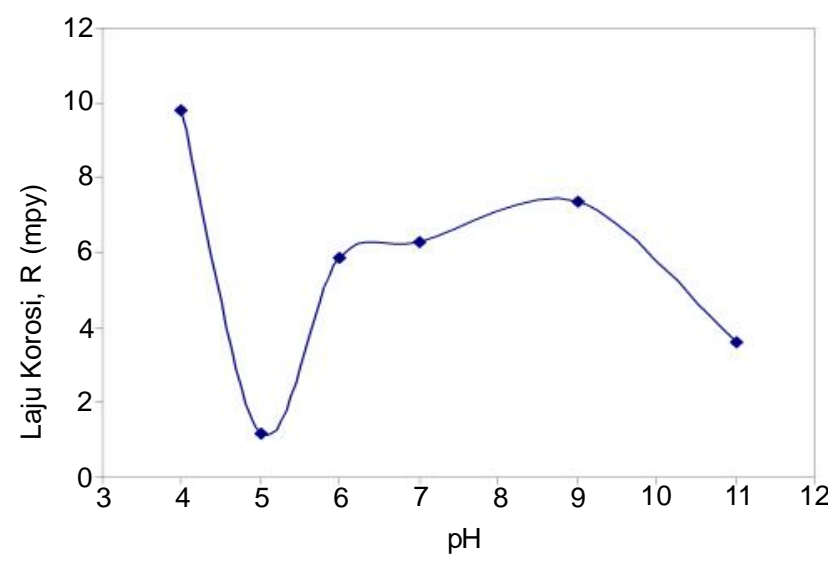

Gambar 5. Hubungan laju korosi pada baja terhadap $\mathrm{pH}$ air

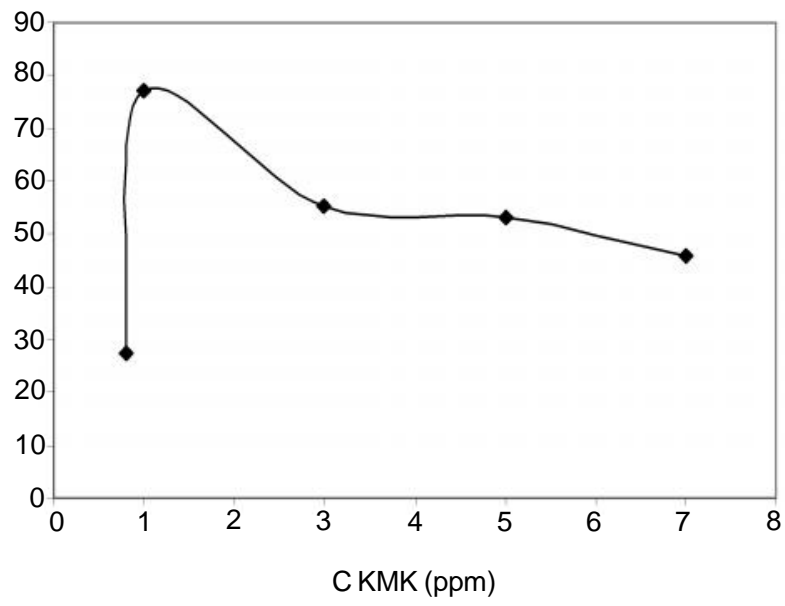

Gambar 6. Efisiensi inhibisi korosi terhadap konsentrasi KMK

arus menjadi lebih rendah. Hasil ini menunjukkan nilai $\mathrm{E}_{\text {corr }}$ menjadi lebih positif yang menyatakan inhibitor termasuk dalam jenis inhibitor anodik. Inhibitor anodik akan diadsorpsi pada bagian yang anodik dan akan menahan terjadinya reaksi korosi pada yang anodik. Karena korosi terjadinya pada anoda, maka penggunaan inhibitor anodik ini sangan efisen. Hanya ada bahayanya yaitu bila inhibitor tidak menutupi seluruh anoda, akan memperluas daerah katoda. Dengan perbedaan luas ini akan menyebabkan intensitas korosi meningkat (Supardi R, 1997).

\section{KESIMPULAN}

Berdasarkan hasil dan pembahasan penelitian dapat dibuat kesimpulan bahwa karboksimetil kitosan yang larut dalam berbagai $\mathrm{pH}$ dan spektrumnya sama dengan referensi adalah karboksimetil kitosan yang disintesis dengan metode Pang, 2007. Karboksimetil kitosan dapat digunakan sebagai inhibitor korosi pada baja lunak dalam media air. Efisiensi inhibisi korosi karboksimetil kitosan pada baja dalam air, optimum terjadi pada $\mathrm{pH} 5$ dan konsentrasi KMK 1 ppm yaitu

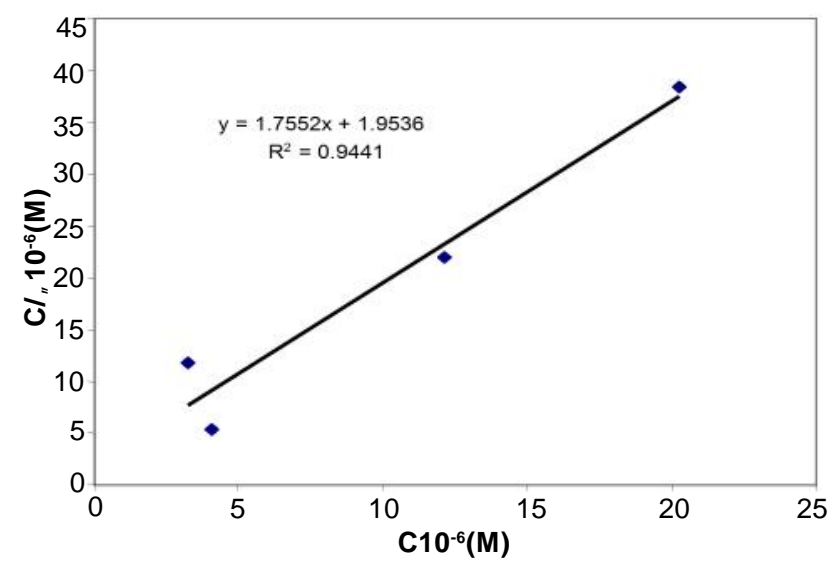

Gambar 7. Plot adsorpsi langmuir untuk inhibitor KMK

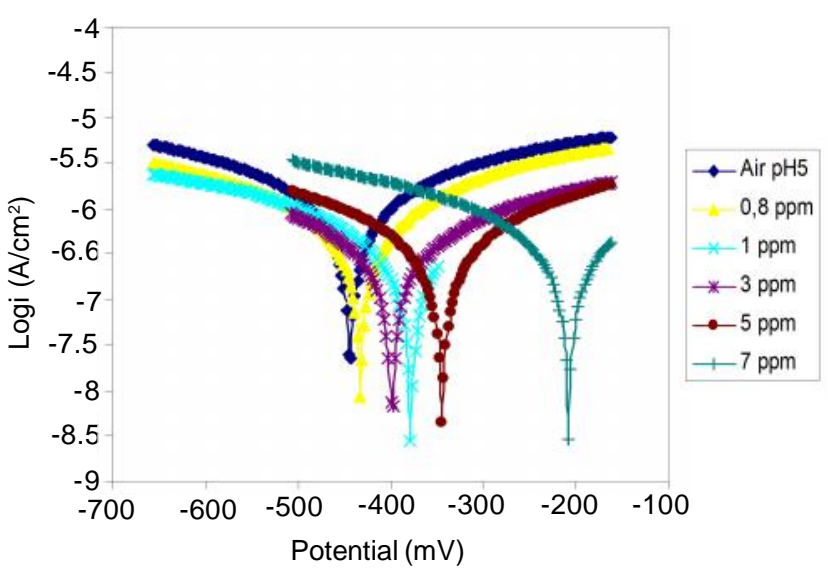

Gambar 8. Kurva potensiadinamik baja dalam air pada $\mathrm{pH} 5$ dengan variasi konsentrasi

mencapai $77 \%$. Jenis mekanisme adsorpsi karboksimetil kitosan pada permukaan baja mematuhi persamaan adsorpsi isotherm Langmuir yaitu termasuk adsorpsi kimia dan bersifat spontan. Jenis inhibitor

karboksimetil kitosan terhadap baja dalam air merupakan inhibitor anodik

\section{UCAPAN TERIMA KASIH}

Peneliti mengucapkan terima kasih atas dana yang diberikan Project IMHERE UR dan DIKTI melalui program Sandwich S3 tahun ajaran 2008/2009 sehingga peneliti dapat melakukan penelitian ini.

\section{DAFTAR PUSTAKA}

Abdallah, M. 2004. Guar Gum as Corrosion Inhibitor for Carbon Steel in Sulfuric Acid Solutions. Portugaliae Electrochimica Acta 22: 161-175

Abiola, O.K., Oforka, N.C., \& Ebenso, E.E. 2004. The Inhibition of Mild Steel Corrosion in an Acidic Medium by Fruit Juice of Citrus Paradisi. The Journal of Corrosion Science and Engineering 5: 1-7.

Bouklah, M., Hammouti, B., Lagrenee, M., \& Bentiss, F. 2006. Thermodynamic properties of 2,5-bis(4methoxyphenyl)-1,3,4-oxadiazole as a corrosion inhibitor for mild steel in normal sulfuric acid medium. Corrosion Science 48: 2831-2842 
De Abreu, F.R \& Campana-Filho, S.P,. 2008. Characteristics and properties of carboxymetyl chitosan. http:// www.elsevier.com/locate/carbpol. 15 Juni 2008.

Jing, M., Li, L., Cheng, G., Gao, C., \& Dong, S. 2008. Preparation of N,O-Carboxymethyl Chitosan Composite Nanofiltration Membrane and its Rejection Performance for the Fermentation Effluent from a wine Factory. Chinese Journal of Chemical Engineering 16: 209-213.

Liang, X., Wang, H., Tian, H., Luo, H., \& Cheng, J. 2008. Synthesis, structure and properties of Novel Quarternized Carboxymethyl Chitosan with Drug Loading capacity. Acta Phys-Chim.Sin. 24: 223-229.

Liu, X.F., Guan, Y.L, Yang, D.Z., Li, Z., \& You, K.D. 2001. Antibacterial action of chitosan and carboxymethylated chitosan. Journal of Applied Polymer Science 79: 1324-1335.

Pang, H.T., Chen, X.G., Park, H.J., \& Keneddy, J.F. 2007. Preparation and rheological properties of deoxycholate chitosan and carboxymehyl-Chitosan in aqueous syatem. Carbohydrate polymer. 69: 419-425.

Rahim, A.A., Rocca, E., Steinmetz, J., Kassim, M.J., Adnan, R., \& Ibrahim, M.S. 2007. Mangrove tannins and their flavonoid monomers as alternative steel corrosion inhibitors in acidic medium. Corrosion Science 49: 402-417.

Sun, L., Du, Y., Fan, L., \& Yang, J. 2006. Preparation, Characterization and Antimicrobial Activity of Quarternized
Caarboxymetyl-Chitosan and Application as Pulp-Cap. Polymer 47: 1796-1804.

Sun, S. \& Wang, W. 2006a. Adsorption Kinetics of $\mathrm{Cu}(\mathrm{II})$ ions Using N,O-Carboxymethyl-Chitosan. Journal of Hazardous Materials 131: 103-111.

Sun, S., Wang, L., \& Wang, A. 2006b. Adsorption Properties of Crosslinked Carboxymetyl-Chitosan Resin with $\mathrm{Pb}(\mathrm{II})$ as Template lons. Journal of Hazardous Materials 136: 930-937

Supardi, R. 1997. Korosi. Edisi Pertama. Bandung, Penerbit Tarsito.

Vincent, S.M. \& Okhio, C.B. 2005. Inhibiting Corrosion with Green Tea. Journal of Corrosion Science and Engineering. 7: 1-10.

Wang, L. \& Wang. A. 2008. Adsorption properties of congo red from aqueaous solution onto N,O-Carboxymethyl-Chitosan. Bioresource Technology 99: 1403-1408.

Xue, X., Li, L., \& He, J. 2009. The Performance of Carboxylmethyl Chitosan in Wash Off Reactive Dyiengs. Carbohydrate Polimer 75: 203-207.

Zhou, L., Wang, Y., Liu, Z., \& Huang, Q. 2006. Carboxymethyl Chitosan- $\mathrm{Fe}_{3} \mathrm{O}_{4}$ nanoparticles: Preparation and adsorption behavior toward $\mathrm{Zn}^{2+}$ ions. Acta phisico-chimikca 22: 13421346. 